\title{
The Impact of the Aging of the Workforce on Wage Growth Over Time
}

\author{
William Seyfried \\ Rollins College
}

It is hypothesized that the aging of the workforce may have altered the sensitivity of wages to change in the unemployment rate. Results of an error-correction model provide support for the existence of a long-run relationship between productivity and real wages, but not between unemployment and real wages. However, a short-run relationship was detected between unemployment and wage inflation, with wages being less sensitive to unemployment for those over the age of 55, indicating that changes in the demographics associated with the aging of the labor force have dampened the magnitude of this relationship, though a significant relationship still endures.

Keywords: wages, compensation, unemployment, productivity

\section{INTRODUCTION}

Much has been written about the aging of the population of the United States as more and more baby boomers reach their retirement years. The implications of the aging of the US population on various aspects of the economy have been explored, including potential impacts on productivity and economic growth (for example, see Bloom, Canning and Fink, 2010; Maestas, Mullen and Powell, 2016). One area that has received scant attention is the potential impact on the behavior of the labor market, including wage growth. Macroeconomic analysis suggests that, from quarter-to-quarter, excess slack in the economy due to high unemployment puts downward pressure on wage growth. Meanwhile, over time, increasing labor productivity drives compensation higher. How do these relationships work? Though compensation may rise more quickly or slowly than labor productivity temporarily, differences in the respective growth rates of compensation and productivity are hard to sustain over time due to the impact on unit labor costs. Unit labor cost is defined as the ratio of compensation per hour divided by labor productivity (output per hour of work). If compensation rises more slowly than labor productivity, unit labor cost declines making labor relatively less expensive, increasing the demand for labor (everything else equal). If compensation rises more quickly than labor productivity, unit labor cost rises, making labor more expensive, reducing the demand for labor. Thus, over time, one would expect that compensation and labor productivity would increase at a similar rate.

Why wouldn't compensation and labor productivity increase at the same rate from year-to-year? When the economy is weak such that unemployment is high, there will be a surplus of qualified workers, putting downward pressure on compensation. Likewise, when unemployment is relatively low, there is likely to be shortages of qualified workers, putting upward pressure on compensation. Thus, the growth in compensation may experience periods of relative weakness and strength, depending on the state of the economy. 
Limited research has been published recently regarding the relationship between wage inflation and slack in the labor market (for example, see Knotek and Zaman, 2014). A preliminary search suggests that most previous studies have not accounted for the long-term impact of productivity growth when analyzing the behavior of compensation.

After a review of the literature, a statistical model will be developed to estimate how changes in the unemployment rate and trend growth in labor productivity impact the growth rate of various forms of wage growth. If significant relationships are found between wage growth and both unemployment and productivity, it would help to explain the sluggishness of compensation growth prior to the pandemic in that productivity growth had been quite low since 2010 and unemployment remained high much longer than usual in the aftermath of the Great Recession.

\section{REVIEW OF THE LITERATURE}

Though there had been considerable research on the relationship between wage inflation and unemployment following Phillips' seminal article in 1958, research activity has been more limited recently. Several economists have explored the relationship in the United States in recent decades. Fee and Schweitzer (2011) examined the relationship between unemployment and labor cost and concluded that high unemployment depressed compensation growth during the last three recessions (1990-91, 2001, 20072009). They use the employment cost index, which includes wages and salaries as well as various forms of benefits, though they decompose the index into wage growth and benefits growth for some of their analysis. A limitation cited in the use of the employment cost index is that it only goes back to the early $1980 \mathrm{~s}$. A consistent pattern is identified during the three business cycles during this period. Wage growth tended to decline following the peak unemployment rate, but the wage growth rate did not respond to declining unemployment. Applying a similar methodology to Stock and Watson (2011), they found that, during the 1990s economic expansion, compensation growth did not pick up until 1999 while during the 2000s expansion, compensation growth did not pick up until the end of the expansion in 2007. Among the conclusions they drew were that the increase in unemployment significantly reduced compensation growth while declines in unemployment rates did not result in an immediate acceleration in compensation growth.

Knotek and Zaman (2014) explored the relationships between wages, prices, and economic activity. Three possible measures of compensation are considered: average hourly earnings, compensation per hour, and the employment cost index. Both compensation per hour and the employment cost index include fringe benefits with the latter abstracting from the composition of the employment over the business cycle, which limits composition bias. All three measures tend to move together over time (including slower growth in the early 2010s), with compensation per hour being the most volatile. Next, they considered crosscorrelations between economic activity and alternative measures of price inflation and wage inflation (where economic activity is measured by the gap between the unemployment rate and the natural rate of unemployment as estimated by the Congressional Budget Office). Negative correlations between economic activity and the various measures of wage inflation were found for up to 6 quarters back with the strongest correlation between economic activity and the employment cost index. Further evidence of a relationship between economic activity and wage inflation is detected by estimating a simple Philips-curve model of wage inflation on lagged wage inflation (up to 4 lags) and the current unemployment gap (for periods beginning in 1960 and 1984, respectively). Significant negative relationships were found in each case with the strongest relationship found for average hourly earnings.

Galí (2011) developed a theoretical, New Keynesian model of the determinants of wage inflation. Next, he estimated the model using both average hourly earnings and compensation. Using data from 1984 onwards, he found a significant, negative relationship between the unemployment gap (using a constant natural rate of unemployment) and wage inflation with a correlation coefficient of -0.76 between the unemployment gap and hourly earnings and -0.27 between the unemployment gap and compensation. Based on estimations of alternative forms of the theoretical model, he concluded that, even under the assumption of a constant natural rate of unemployment, the model does a good job in explaining the strong negative 
co-movement between wage inflation and unemployment, even in the presence of two decades of price stability.

Daly, Hobijn, and Wiles (2012) noted that many studies have found a smaller effect of unemployment on wage inflation than one would expect. They address this by distinguishing between the wage growth effect and the composition effect. The wage growth effect is what is normally considered. As unemployment increases, aggregate wage inflation tends to diminish as more qualified workers become available. However, aggregate wage inflation doesn't diminish as much as one would expect since the composition of workers changes. Typically, lower skilled workers earning lower wages tend to be the first to lose their job when the economy sours. As a result, aggregate wages do not decline as much. Wage inflation is proxied by the growth in median weekly earnings divided by the PCE index (though they show that it is correlated with other measures, such as average hourly earnings and compensation per hour). They found that the relative importance of the effects differs over the business cycle, with the wage growth effect normally having the dominant impact, but the composition effect plays a greater role during downturns, offsetting up to half of the wage growth effect. During tight labor markets, job switchers play a large role in explaining wage inflation.

Bivens and Mishel (2015) explored the relationship between pay (including fringe benefits) and productivity and conclude that pay and productivity have diverged significantly since 1973. Much of their conclusion rests on the methodology employed. They proxied pay using inflation-adjusted hourly pay (median and average), making use of CPI-U-RS to adjust for inflation and hourly pay for private sector production/nonsupervisory workers. Productivity was measured using net productivity for all workers and also makes use of CPI-U-RS to adjust for inflation (CPI-U-RS is similar to the more commonly known CPI-U, which most people refer to as the CPI, except that it makes corrections for past problems in measuring the cost of housing). Thus, productivity reflects all workers whereas pay reflects select workers (nonsupervisory, nongovernment, etc.). Also, economic theory suggests that compensation should reflect the value of the marginal product of labor in a market economy where the value of the marginal product is the marginal product multiplied by the price of the item produced. Since productivity is proxied by nonfarm business output per hour of work, theory indicates that the appropriate price is the nonfarm implicit price deflator. Bivens and Mishel stated that the purpose of their study was to consider the impact on workers, so they use the CPI instead, since it helps to measure consumer purchasing power. Also, they rationalized using pay for nonsupervisory workers since they want to "highlight just how far behind productivity growth the pay of most American workers has lagged." This raises concerns since pay and productivity do not reflect the same populations.

Feldstein (2008) pointed out that compensation and productivity increased at similar rates between 1970 and 2006. This can be seen in terms of the nominal growth rates of each over that period and little change in the ratio of compensation to national income. If one deflates both compensation and nominal productivity using the same deflator, the growth of each is also similar in real terms. He went on to make the theoretical case that the most appropriate deflator is the price deflator for the nonfarm business sector since productivity is measured for that sector. Feldstein notes that the relationship between productivity and compensation is not expected to be one-for-one in a given year due to cyclical influences. His empirical results reveal a correlation of 0.79 using contemporaneous annual data, but when employing two lags, the coefficients sum to 0.94 , not statistically different from one.

Preliminary conclusions based on the literature provide evidence for a relationship between unemployment and wage inflation, regardless of the measure of compensation used. The relationship appears to occur with a lag and is evident even independent of the natural rate of unemployment (for example, Gali (2011) uses a constant natural rate). Separately, Feldstein detected a high correlation between productivity and wage growth, not statistically different from one, when employing two lags using annual data. A missing element of the research is the effect that changes in the age composition of the labor force may have on the relationship between unemployment and wage inflation. 


\section{DATA ANALYSIS}

The demographics of the US labor market have changed significantly in recent decades. One aspect of that change results from the aging of the baby boomers (oftentimes characterized as those born shortly after World War 2 until the early 1960s). Baby boomers began to enter the labor market in the mid-1960s, with the last members making their entrance in the early 1980s. The oldest members of this generation reached their mid-50s early in the new century, continuing to do so through the mid-2010s. This is evidenced by the aging of the work force, as seen in figure 1 (data obtained from the Federal Reserve Economic Database).

\section{FIGURE 1
PERCENT OF WORKERS 55 AND ABOVE, 1964-2019}

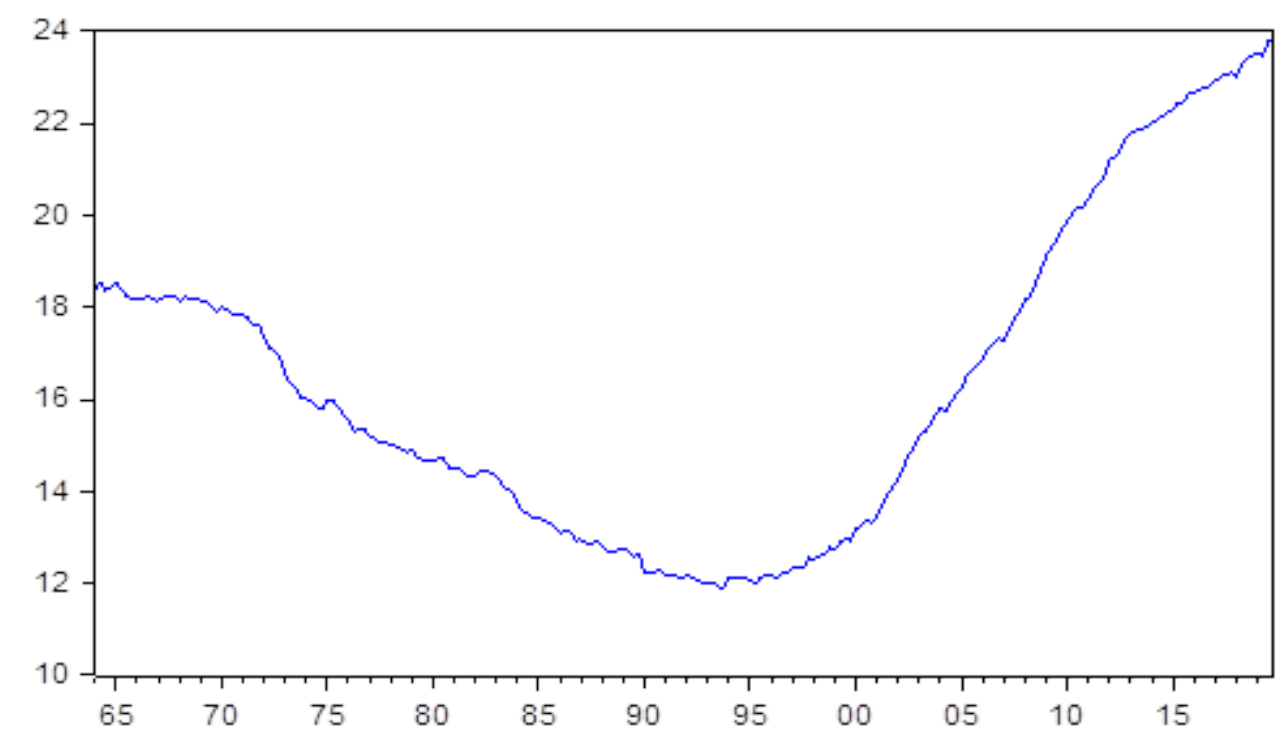

As can be seen in figure 1, approximately $18.5 \%$ of those employed were 55 and older in the mid$1960 \mathrm{~s}$, declining to about $12 \%$ in the early $1990 \mathrm{~s}$, before rising to $24 \%$ recently. The doubling of the proportion of older workers in the labor market during the last couple of decades raises the issue as to whether the change in the age composition of workers impacted the behavior of labor market?

How may the changing age composition of the workforce impact the behavior of compensation over time? While the relationship between productivity and wages may remain unaffected, the cyclical behavior of wages may change as the sensitivity of wages to unemployment is altered. A common perspective among most economists is that lower rates of unemployment put upward pressure on wages as shortages of workers arise. The wages of workers who are the most likely to be active in the job market would be expected to be most affected. During times in which the job market is tight, companies are more likely to give raises to those most likely to leave for perceived better opportunities in order to retain those workers. A recent report from the BLS (2020) confirms that employee tenure (length of time with one's current employer) rises with age. For example, those 35-44 display a median tenure of about five years while those age 55-64 exhibit a median tenure of about ten years (a similar pattern is evident over time). This implies that older workers are less likely than younger workers to seek better opportunities and thus their wages and salaries would be expected to be less sensitive to changes in the unemployment rate. Given that the proportion of older workers in the labor market has doubled since the mid-1990s, the sensitivity of aggregate wages for all workers to changes in unemployment may have diminished compared to previous periods.

Though a variety of measures have been used to proxy compensation, a measure that has received more attention in recent years is median wage growth, which is included in the Atlanta Fed wage tracker (Wage Growth Tracker, 2021). Median wage growth for various demographics are available including by age, 
education, and race (in addition to by industry and occupation). Productivity was measured as the real output per hour worked in the nonfarm business sector (the nonfarm business sector excludes the activities of government, private households, and nonprofits serving individuals and farms). When economists posit the relationship between labor productivity and wages over time, they are considering the underlying trend in the growth of productivity, removing cyclical fluctuations (as explained earlier, short-term changes in productivity are unlikely to impact wages). A Hodrick-Prescott filter (Hodrick and Prescott, 1997) was used to identify the underlying trend in productivity growth during the period in question (see figure 2).

\section{FIGURE 2 \\ TREND GROWTH IN LABOR PRODUCTIVITY}

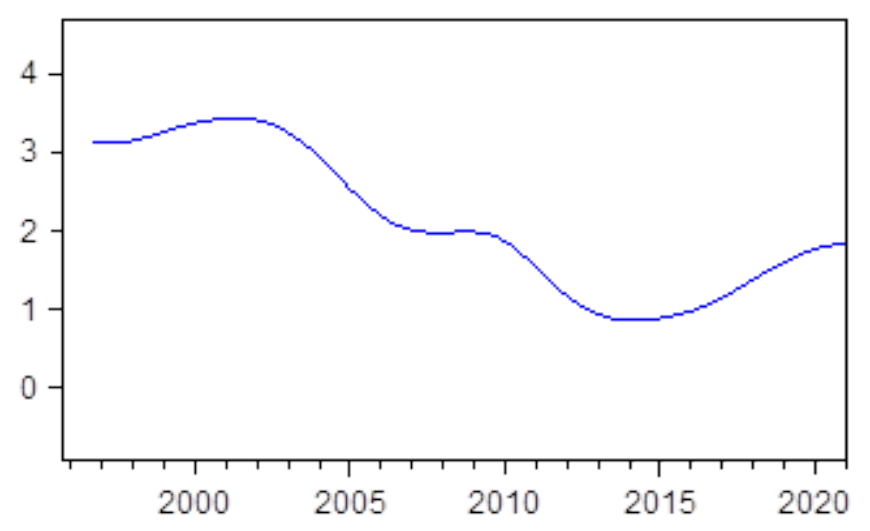

When evaluating the impact of productivity and the unemployment rate on wages, the wage under consideration is the real wage (adjusted for inflation), not the nominal wage. As with productivity, cyclical fluctuations in inflation could introduce distortions in evaluating the behavior of real wages. Underlying trends in inflation or expected inflation are more relevant in estimating the real wage. As such, a HodrickPrescott filter was used to identify the underlying trend in core PCE inflation (a preferred measure by the Fed; see Federal Reserve, 2016). The growth of the various forms of real wages were estimated using trend inflation to adjust the median wage growth (see figure 3 ).

\section{FIGURE 3 \\ BEHAVIOR OF MEDIAN REAL WAGE, 1998-2019}

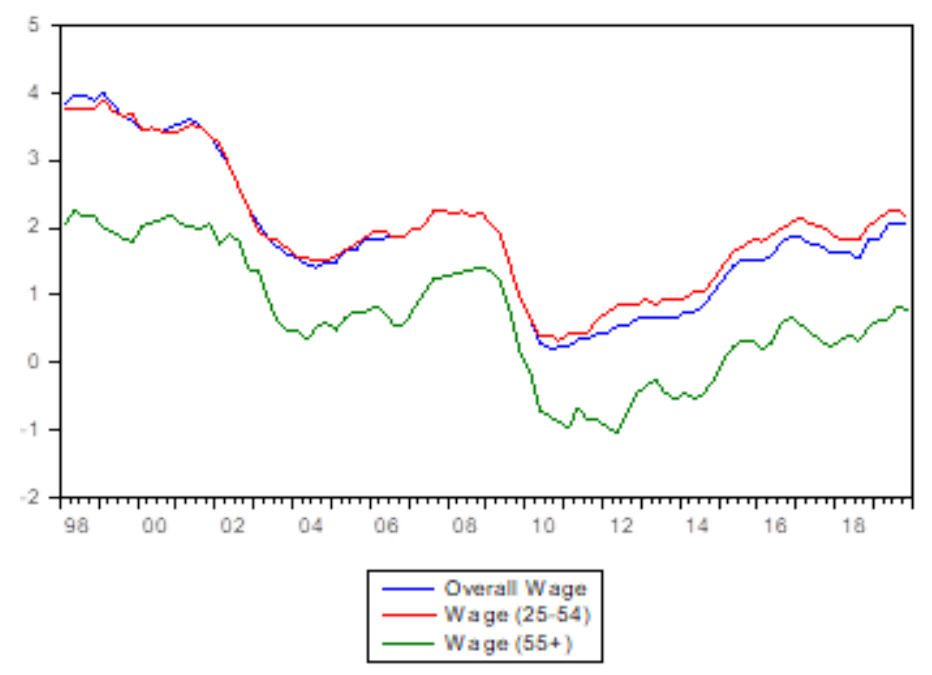




\section{EMPIRICAL MODEL AND RESULTS}

A statistical model was developed to estimate how changes in the unemployment rate and labor productivity impact wage growth. In order to disentangle short-run (cyclical) and long-run (structural) effects, an error-correction model (ECM) was employed. As discussed earlier, economic theory suggests that the primary impact of labor productivity on wages is expected to take place in the long run while changes in the unemployment rate are more likely to affect wages in the short run. An error-correction model allows one to separate long-run relationships, using cointegration, from short-run effects. In order to proceed with the ECM, one must first test for stationarity of the variables in question by testing for unit roots. If all the variables are stationary, one can move forward with the development and estimation of the ECM. Results of an Augmented Dickey-Fuller tests (Dickey and Fuller, 1981; Cheung and Lai, 1995) indicated that all the variables were I(1), allowing one to move forward with the ECM in terms of first differences.

TABLE 1

\section{ADF TEST FOR UNIT ROOTS}

\begin{tabular}{|l|c|}
\hline & $\mathrm{I}(1)$ \\
\hline Trend Productivity & $-2.861^{*}$ \\
\hline Unemployment rate & $-3.248^{*}$ \\
\hline Median growth in real wage & $-14.984^{* *}$ \\
\hline Median growth in real wage (25-54) & $-14.053^{* *}$ \\
\hline Median growth in real wage (55+) & $-8.037^{* *}$ \\
\hline
\end{tabular}

$*$ indicates significance at $5 \%$ level; $* *$ indicates significance at $1 \%$ level

The ECM was estimated with the results reported in tables 2-3. Table 2 displays the results of the cointegration test while table 3 shows the results of the respective ECMs, including the estimated adjustment coefficient (coefficient on cointegration(-1)) and estimates of the relationship between median real wage growth and lagged values for each variable (median real wage growth, trend productivity, and the unemployment rate).

Results of the cointegration test provide evidence of a long-run relationship between trend productivity growth and each measure of the median real wage growth, but no long-run relationship between the unemployment rate and median real wage growth. For both the overall median real wage and median real wage for those between 25 and 54, the coefficient is not statistically different from one (the t-statistics are 1.22 and 0.99 , respectively), indicating a proportionate relationship between productivity growth and the growth of median real wages over time, while the coefficient for the wage for those 55 and above is 0.82 (statistically less than one), implying a slightly less than proportionate relationship. This provides support to the expected long-run relationship based on the theory described earlier.

TABLE 2

COINTEGRATION: WAGE, PRODUCTIVITY AND UNEMPLOYMENT RATE

\begin{tabular}{|r|c|c|c|}
\hline & Overall Wage & Wage (25-54) & Wage (55+) \\
\hline Wage & 1.0000 & 1.0000 & 1.000000 \\
\hline $\mathrm{C}$ & 1.231974 & 0.477522 & 0.463336 \\
\hline Trend productivity & -1.091696 & -1.080998 & -0.823808 \\
& $(0.07541)$ & $(0.08189)$ & $(0.05628)$ \\
\hline Unemployment rate & -0.078571 & -0.040122 & 0.095468 \\
& $(0.05225)$ & $(0.04587)$ & $(0.06118)$ \\
\hline
\end{tabular}

(standard errors in parentheses) 
TABLE 3

ERROR CORRECTION MODEL OF D(WAGE)

\begin{tabular}{|r|c|c|c|}
\hline & DWAGE & DWAGE(25-54) & DWAGE(55+) \\
\hline Cointegration (-1) & $0.097710^{*}$ & $-0.099725^{*}$ & $-0.282672^{* *}$ \\
& $(0.06012)$ & $(0.06091)$ & $(0.10928)$ \\
\hline C & -0.022073 & -0.003263 & -0.000813 \\
& $(0.01838)$ & $(0.01875)$ & $(0.02073)$ \\
\hline DWAGE(-1) & -0.033483 & -0.005874 & 0.023062 \\
& $(0.02217)$ & $(0.02267)$ & $(0.05248)$ \\
\hline DWAGE(-2) & 0.023174 & 0.001326 & $0.083211^{*}$ \\
& $(0.02175)$ & $(0.02248)$ & $(0.04864)$ \\
\hline DWAGE(-3) & -0.004412 & -0.000291 & 0.015723 \\
& $(0.02174)$ & $(0.02224)$ & $(0.05062)$ \\
\hline DWAGE(-4) & -0.030383 & -0.013048 & -0.057645 \\
& $(0.02169)$ & $(0.02227)$ & $(0.04773)$ \\
\hline DPRODUCTIVITY(-1) & 18.62233 & 27.36089 & 58.72911 \\
& $(30.2010)$ & $(28.5395)$ & $(43.2022)$ \\
\hline DPRODUCTIVITY(-2) & -30.19485 & -41.28902 & -159.2162 \\
& $(76.9592)$ & $(73.1752)$ & $(114.724)$ \\
\hline DPRODUCTIVITY(-3) & 9.128543 & 12.01650 & 161.3223 \\
& $(70.3768)$ & $(67.2841)$ & $(107.618)$ \\
\hline DPRODUCTIVITY(-4) & 2.572648 & 3.060532 & -59.30626 \\
& $(22.9873)$ & $(22.0522)$ & $(35.6740)$ \\
\hline DUNEMPLOYMENT(-1) & -0.007998 & 0.049057 & 0.098635 \\
& $(0.04198)$ & $(0.04118)$ & $(0.07037)$ \\
\hline DUNEMPLOYMENT(-2) & -0.027127 & -0.054243 & 0.105051 \\
& $(0.04640)$ & $(0.04596)$ & $(0.07528)$ \\
\hline DUNEMPLOYMENT(-3) & $-0.125983 * *$ & $-0.152770 * * *$ & 0.054843 \\
& $(0.05379)$ & $(0.05271)$ & $(0.08544)$ \\
\hline DUNEMPLOYMENT(-4) & $-0.110063 * *$ & -0.065506 & $-0.267969 * * *$ \\
& $(0.05107)$ & $(0.05000)$ & $0.07794)$ \\
\hline & 0.553685 & 0.541904 & 0.452558 \\
\hline
\end{tabular}

*indicates significance at the $10 \%$ level; ** indicates significance at the $5 \%$ level; *** indicates significance at the $1 \%$ level

Results of the ECM indicate that there's not a short-run relationship between trend productivity and median real wage growth, but provides evidence for a short-run relationship between the unemployment rate and median real wage growth for each age group as well as overall. The estimated coefficient on the respective lagged cointegration terms indicate marginal significance for the adjustment to the long-run equilibrium for the median real wage and median real wage (25-54) with a higher level of significance for the median real wage (55+). Given the use of multiple lags of the unemployment rate, the magnitude of the relationship between unemployment and the median real wage is best estimated by a Cholesky Impulse Response Function (Sims, 1980) in the form of the impact of a one-standard deviation innovation in the unemployment rate on the median real wage, using the empirical results of the respective ECMs. Figures 4-6 display the response for the respective wages over ten quarters. As is evident, the sensitivity of the respective wages to unemployment differ for each measure. In each case, a one standard deviation increase in the unemployment rate has a minimal impact for the first few quarters with a negative impact becoming more evident in the fourth quarter and into the second year. After ten quarters, a one standard deviation increase in the unemployment rate results in a .25 reduction in the growth rate of the overall median rea 
wage and a similar, though slightly larger, reduction of 0.28 for median real wage (25-54), but only 0.16 for median real wage for those 55 and over. This provides support for the diminished sensitivity of wages to changes in unemployment for older workers.

FIGURE 4

RESPONSE OF MEDIAN REAL WAGE TO A CHANGE IN UNEMPLOYMENT RATE

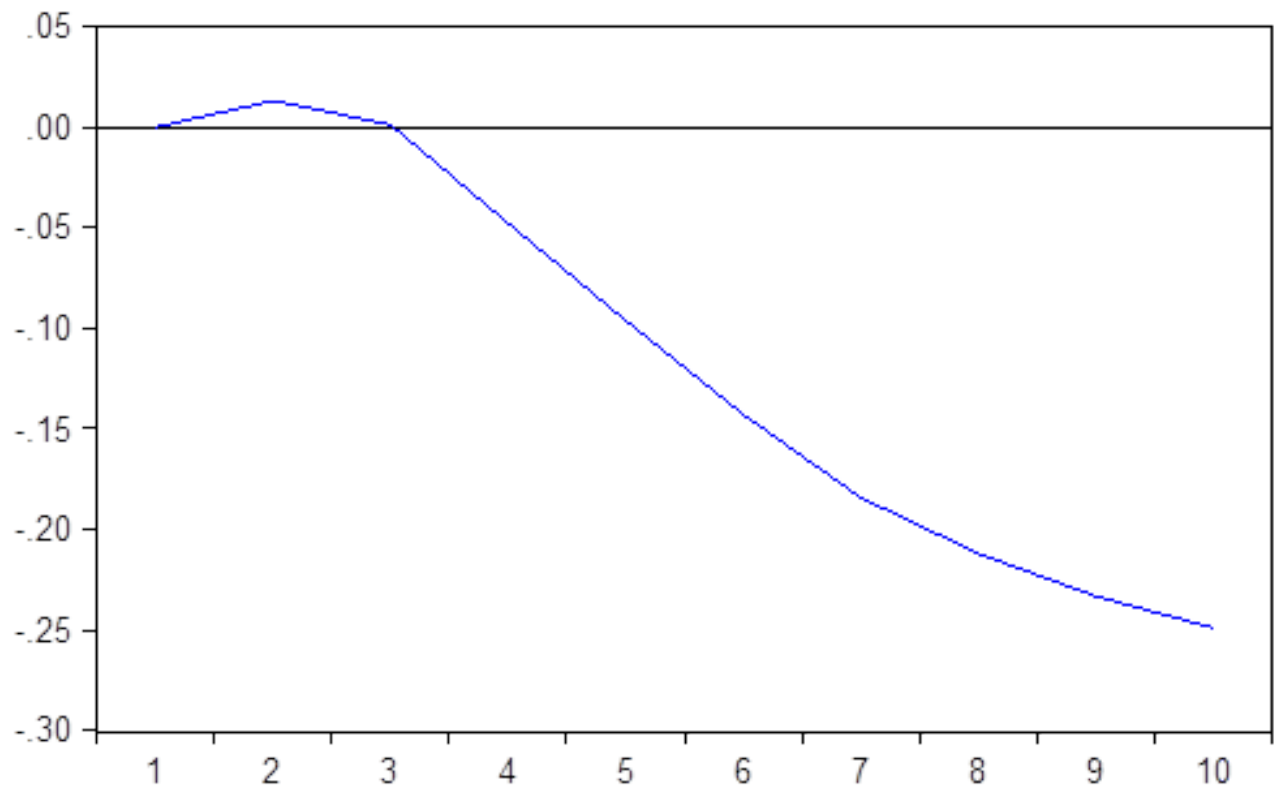

FIGURE 5

RESPONSE OF MEDIAN REAL WAGE (25-54) TO A CHANGE IN UNEMPLOYMENT RATE

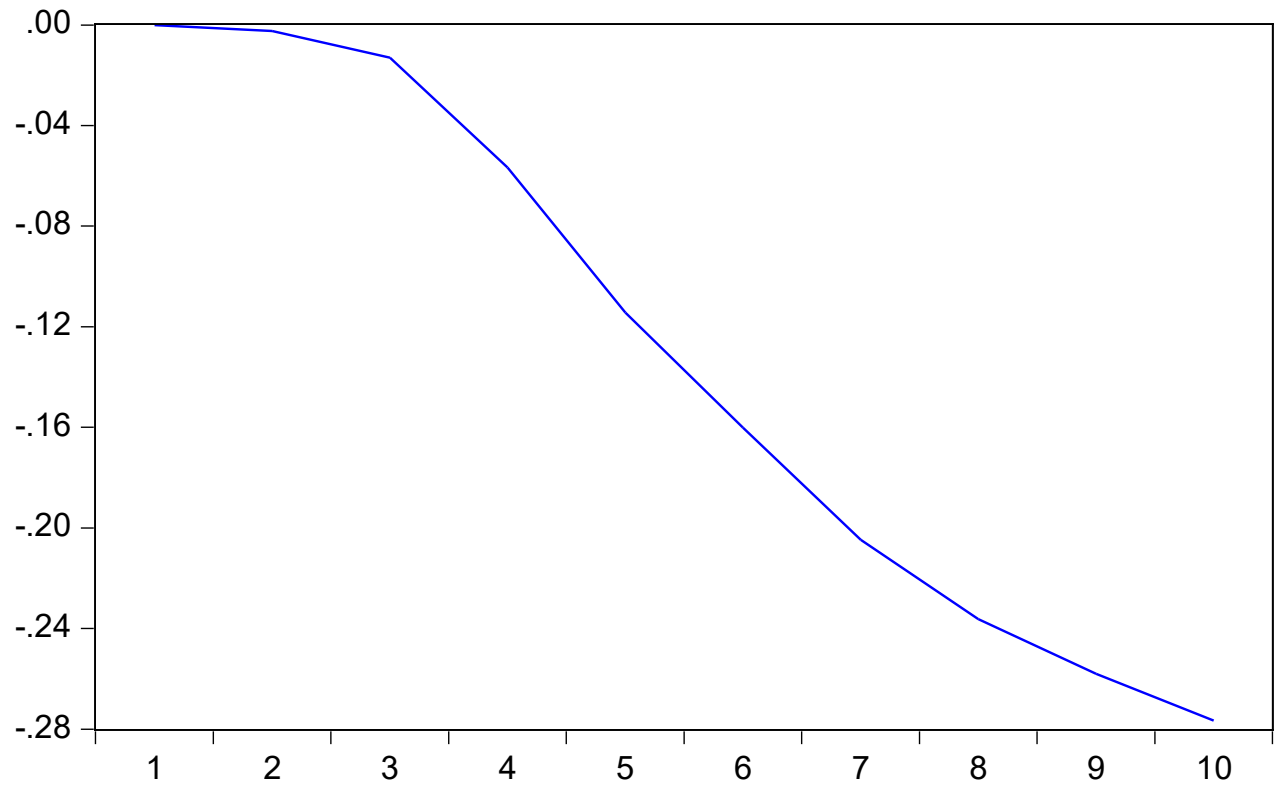


FIGURE 6

\section{RESPONSE OF MEDIAN REAL WAGE (55+) TO A CHANGE IN UNEMPLOYMENT RATE}

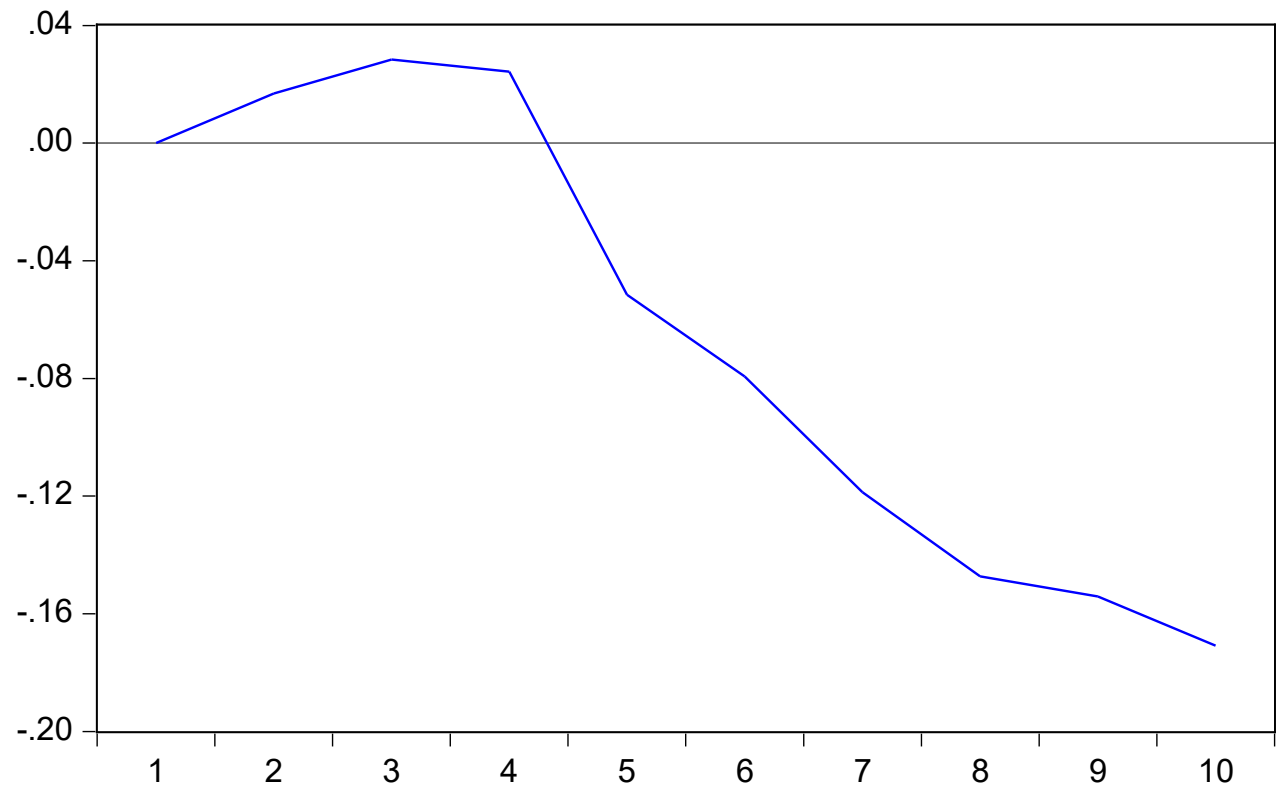

\section{CONCLUSION}

Economists have long recognized a relationship between unemployment and wage inflation (for example, see Phillips, 1957). Though unemployment is thought to impact wages in the short run, most think that there is no long-run relationship (see Phelps 1968, for the seminal article). In the long run, it is thought that real wage growth is driven by growth in productivity. A question arises, though these relationships may exist, what about the magnitude of the relationships? The demographics of the U.S. labor market have changed considerably in recent decades as the aging of baby boomers has led to a doubling of the proportion of workers over the age of 55; increasing from 1 in 8 in the mid-1990s to 1 in 4 recently. Data and economic reasoning suggest that older workers are less affected by changes in labor market conditions, such that changes in the overall unemployment rate should have less impact on the wages of older workers than those in their prime working age (25-54). As older workers make up a larger percentage of workers, one would expect this to impact the sensitivity of overall wages to changes in unemployment.

In line with economic theory, results of an error-correction model provide support for the existence of a long-run relationship between productivity and real wages, but not between unemployment and real wages. However, a short-run relationship was detected between unemployment and real wage inflation, with a lower magnitude for those over the age of 55 (as postulated based on economic reasoning). Together, the results provide evidence supporting how changes in the unemployment rate impacting real wages in the short run with productivity being a major determinant of real wages over time. Changes in the demographics associated with the aging of the labor force have dampened the magnitude of the relationship between wage inflation and unemployment, though a significant relationship still endures. 


\section{REFERENCES}

Bivens, J., \& Mishel, L. (2015). Understanding the Historic Divergence between Productivity and a Typical Worker's Pay. Economic Policy Institute Briefing Paper \#406.

Bloom, D.E., Canning, D., \& Fink, G. (2010). Implications of Population Ageing for Economic Growth, Oxford Review of Economic Policy, 26(4), 583-612.

Cheung, Y.W., \& Lai, K.S. (1995). Lag Order and Critical Values of the Augmented Dickey-Fuller Test. Journal of Business and Economic Statistics, 13(3), 277-280.

Daly, M.C., Hobijn, B., \& Wiles, T.S (2012). Dissecting Aggregate Real Wage Fluctuations: Individual Wage Growth and the Composition Effect. Federal Reserve Bank of San Francisco Working Paper Series, pp. 2011-23.

Dickey, D.A., \& Fuller, W.A. (1981). Likelihood Ratio Statistics for Autoregressive Time Series with Unit Root. Econometrica, 49, 1057-1072.

Employee Tenure in 2020. (2020). BLS. Retrieved from https://www.bls.gov/news.release/pdf/tenure.pdf

Fee, K., \& Schweitzer, M. (2011). Unemployment, Labor Costs, and Recessions: Implications for the Inflation Outlook. Federal Reserve Bank of Cleveland Economic Commentaries. Retrieved from https://www.clevelandfed.org/newsroom-and-events/publications/economiccommentary/economic-commentary-archives/2011-economic-commentaries/ec-201117unemployment-labor-costs-and-recessions-implications-for-the-inflation-outlook.aspx

Feldstein, M. (2008). Did Wages Reflect Growth in Productivity? Journal of Policy Modeling, 30(4), 591-594.

Galí, J. (2011). The Return of the Wage Phillips Curve. Journal of the European Economic Association, $9(3), 436-461$.

Hodrick, R.J., \& Prescott, E.C. (1997). Postwar U.S. Business Cycles: An Empirical Investigation. Journal of Money, Credit and Banking, 29(1), 1-16.

Knotek, E., \& Zaman, S. (2014). On the Relationship between Wages, Prices and Economic Activity. Federal Reserve Bank of Cleveland Economic Commentaries. Retrieved from https://www.clevelandfed.org/newsroom-and-events/publications/economic-commentary/2014economic-commentaries/ec-201414-on-the-relationships-between-wages-prices-and-economicactivity.aspx

Maestas, N., Mullen, K.J., \& Powell, D. (2016). The Effect of Population Aging on Economic Growth, the Labor Force and Productivity. National Bureau of Economic Research Working Paper \#22452.

Phelps, E. (1968). Money-Wage Dynamics and Labor-Market Equilibrium. Journal of Political Economy, 76(4), 678-711.

Phillips, A.W. (1958). The Relation between Unemployment and the Rate of Change of Money Wage Rates in the United Kingdom, 1861-1957. Economica, 25(100), 283-299.

Sims, C.A. (1980). Macroeconomics and Reality. Econometrica, 48(1), 1-48.

Stock, J., \& Watson, M.W. (2011). Modeling Inflation after the Crisis. Macroeconomic Challenges: The Decade Ahead. Federal Reserve Bank of Kansas City.

The Fed. (2016). What is Inflation and How Does the Federal Reserve Evaluate Changes in the Rate of Inflation? Federal Reserve Board FAQs. Retrieved from https://www.federalreserve.gov/faqs/economy_14419.htm

Wage Growth Tracker. (n.d.). Center for Human Capital Studies. Federal Reserve Bank of Atlanta, Retrieved May 10, 2021, from https://www.atlantafed.org/chcs/wage-growth-tracker 